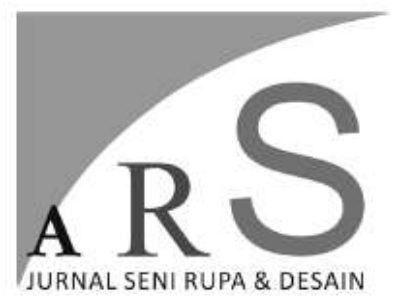

Volume 22 Nomor 3, Desember 2019

\section{KREATIFITAS YANG "LAIN" \\ IDENTIFIKASI KARYA RADEN SALEH DAN BASOEKI ABDULLAH PADA LUKISAN SENIMAN MODERN}

\author{
Amir Hamzah \\ Program Studi Seni Rupa Murni, Jurusan Seni Murni \\ Fakultas Seni Rupa, Institut Seni Indonesia Yogyakarta
}

\begin{abstract}
ABSTRAK
Seniman modern Jawa Raden Saleh dan Basoeki Abdullah memilih melukis secara modern menghadapkan problem kultural dalam penciptaanya. Terdapat keyakinan bahwa melukis orisinalitas seorang seniman modern menjadi tuntutan utama, membuat karya yang baru sebagai bentuk kreatifitas yang berkepribadian, mereka juga melakukan kreatifitas dengan mengidentifikasi terhadap karya yang sudah ada dianggap memiliki nilai yang negatif. Kita dapat memandangnya sebagai bentuk kreatifitas "lain" dari seni rupa modern. Sebagai agen yang menghadapi struktur kreatifitas mereka ditelaah dalam habitus, modal dan arena yang mereka jalani.
\end{abstract}

Kata kunci: Raden Saleh, Basoeki Abdullah, identifikasi, problem kultural

\begin{abstract}
Modern Javanese artists Raden Saleh and Basoeki Abdullah chose to paint in a modern way with cultural problems in their creation. There is a belief that painting the originality of a modern artist becomes the main demand, making new works as a form of creative personality, they also do creativity by identifying existing works that are considered to bave negative values. We can see it as a form of "other" creativity from modern art. As agents who face the structure of their creativity, they are examined in the babitus, capital and arena they live in.
\end{abstract}

Keywords: Raden Saleh, Basoeki Abdullah, identification, cultural problems

\section{Pendahuluan}

Raden Saleh dan Basoeki Abdullah adalah seniman modern yang sangat terkenal di Indonesia, begitu besarnya nama kedua tokoh ini hingga membuat kehidupan mereka diselimuti oleh banyak mitos. Raden Saleh menjadi pelukis yang dianggap sangat luar biasa dari segi teknis sehingga konon orang tidak lagi dapat membedakan antara lukisannya dan kenyataan, Basoeki Abdullah dipercaya sebagai seniman yang dapat menciptakan lukisan potret lebih cantik dari modelnya.

Kedudukan dua tokoh ini terutama dalam seni rupa modern Indonesia sangat penting, Raden Saleh dianggap sebagai orang Jawa pertama yang melukis secara modern, sedangkan Basoeki Abdullah adalah seniman yang konsisten melukis keindahan yang secara mudah dapat dinikmati dan diterima orang banyak, walaupun dalam perjalanannya mendapat penentangan hingga mempertanyakan jiwa nasionalismenya.

Sebagai seniman modern dari Jawa yang mendalami ilmu barat, Raden Saleh dan Basoeki Abdullah berusaha menempatkan diri sebagai seniman modern dalam melukis, menciptakan dengan kreatifitas, mencapai kebaruan dan mencari karakteritik keseniannya. 
Disamping itu mereka juga menjalani kreatifitas yang 'lain', Raden Saleh dan Basuki Abdullah memiliki beberapa karya teridentifikasi dengan karya seniman modern Eropa. Lukisan Raden Saleh tentang Penangkapan Diponegoro mau tidak mau selalu diidentikkan dengan lukisan Pieneman, sedangkan Banjir di Jawa memiliki struktur yang sama dengan Rakit Medusa milik Gericault. Begitu pula terhadap kreatifitas Basoeki Abdullah, melalui lukisan berburu singanya teredintifikasi dengan karya Rubens, juga banteng yang mirip dengan kebakaran hutan milik Raden Saleh, atau letusan gunung Krakatau yang identik dengan lukisan Edwin Curch. Mengapa hal tersebut terjadi?

Semangat modern pada masa Avand Gard menuntut seniman untuk menunjukkan identitasnya yang orisinal, namun tidak dapat dipungkiri bahwa kreatifitas manusia berjalan bukan dalam ruang yang kosong, sudah sejak lama proses mengidentik dengan karya lukisan yang sebelumnya ada banyak dilakukan oleh seniman. Persoalan yang akan dikemukakan dalam konteks Raden Saleh dan Basoeki Abdullah adalah problem kultural mereka sehingga melakukan kreatifitas yang 'lain', ketika semangat senirupa modern kemudian harus berhadapan dengan konteks tertentu, hingga lahirnya sebuah karya dipengaruhi atas benturan seniman sebagai agen yang harus berhadapan dengan struktur dalam kehidupannya.

Secara kualitatif yang dekskriptif persoalan proses mengidentifikasi Raden Saleh dan basoeki Abdulah akan diterangkan, lebih lanjut oleh Sumartono mengemukakan mengemukakan metode ini yaitu: tentang studi kasus dengan mengekplorasi atau menjelajahi sebuah entitas tunggal atau sebuah gejala/fenomena (kasus) yang diikat oleh waktu dan aktifitas (sebuah program, sebuah proses, sebuah lembaga institusi, atau sebuah kelompok sosial) dan mengumpulkan informasi secara detail dengan menggunakan prosedur pengumpulan data dalam sebuah jangka waktu tertentu (Sumartono, 2017: 97).

Pemaparannya dilakukan dengan deskriptif analitik (Ratna, 2010: 336). Memaparkan sekaligus menganalisis problem kultural yang melatar belakangi lahirnya ekspresi seniman modern Raden Saleh dan Basoeki Abdullah yang identik dengan karya seniman Eropa. Instrumennya adalah data biografi yang dapat menunjukkan konteks dan sejarah seniman, dan penulis juga akan menentukan karya-karya yang menjadi objek dalam penelitian berkaitan dengan identifikasi visual yang menurut penulis relevan.

\section{Kreatifitas yang "Lain" Seni Rupa Modern}

Dinamisnya perkembagan seni rupa modern sejak zaman Neoklasik di Eropa memuncukan banyaknya aliran-aliran dalam berkarya, munculnya semangat aliran akan dikoreksi, diiringi, atau diperbaharui dengan aliran lain, puncak dari kepercayaan diri modern sebagai seniman garda depan (Avand Gard) dalam semangat Kreatifitas, Orisinalitas dan Novelty (Yustiono dalam Annas, 2000). Secara garis besar kemajuan seni rupa baik pemikiran dan teknik berkarya menemui jalannya dalam peradaban dengan mapannya infra struktur yang mendukungnya.

Sejarah juga menunjukkan bahwa proses kreatifitas manusia bergerak bukan di ruang kosong. Seni rupa mainstream menjelajah memasuki ruang-ruang menjauhi sumbernya, di satu sisi terjadi penganyaan materi visual dengan mengadopsi artefak tradisional, di sisi lainnya memunculkan modernitas sebagai sebuah keniscayaan pada wilayah yang dimasukinya. Modernitas tentu dibarengi dengan upaya mencari karakteristik asli yang memiliki semangat modern.

Rumusan-rumusan dalam berkarya yang melandasi konsep berfikir para seniman memberi imbas pada penciptaan karya seni, tuntutan semangat modern dalam sejarahnya tak dapat membentuk kreatifitas yang "lain", dari mengambil unsur klasik yang sebenarnya tidak baru lagi pada Renaisans dan Neoklasik, konsep ready made yang semena-mena mengambil alat atau bahan sehari-hari menjadi objek seni, hingga copyng baik Quoting mengambil sebagaian dan merangkainya, maupun Apropriasi dengan sengaja mencomot karya orang lain dengan pemaknaan baru. $\mathrm{Hal}$ tersebut menjadi jalan kreatifitas atau sebagai sensasi hingga dunia seni rupa berfikir ulang tentang kreatifitas dan orisinalitas. Begitu menggodanya dunia seni rupa, kreatifitas yang 
lain menjadi sebuah keniscayaan dari kehidupan sosial manusia yang terus bergerak seiring berkembangnya pola pikir dan tidak hidup di ruang kosong.

Menurut Kamus Besar identifikasi merupakan proses psikologi yang terjadi pada diri seseorang karena secara tidak sadar dia membayangkan dirinya seperti orang lain yang dikaguminya, lalu dia meniru tingkah laku orang yang dikaguminya itu (Hasan, 2005: 567).

Mengenai proses kreasi yang "lain" sebagaimana penulis maksudkan diterangkan dengan cukup informatif oleh Rifky Effendi, "Dalam Apropriasi: Spektrum Praktek Apropriasi Dalam Seni Rupa Kontemporer di Indonesia", sebuah pengantar pameran Dalam Apropriasi di Galeri Semarang (Effendy, 2007). Dalam tulisannya digambarkan proses kreasi bentuk peniruan serta keabsahannya dalam perspektif sejarah maupun wacana yang dikembangkannya hingga saat ini.

Aktifitas kreatifitas sudah dimulai sejak masa Prasejarah hingga kini, didapati usaha manusia untuk menciptakan sesuatu dengan memesis (peniruan) dari yang sudah ada, Yunani dan Romawi klasik memakai tubuh manusia ideal untuk merepresentasikan Dewadewanya, dilanjutkan jaman kekristenan membuat ikon atas manusia suci dan standarisasi wajah Kristus sehingga kita dapat mengenalinya hingga saat ini.

Masa Renaisans memanggil kembali semangat klasik yang tertutup kabut abad kegelapan, dan kemudian dilanjutkan dalam perkembangan seni rupa masa Neoklasik, yang tidak sekedar mengambil semangat klasik Yunani dan Romawi kuno, namun juga mengadopsi dalam kebentukan, menghadirkan perangkat perangkat klasik dalam seni rupa saat itu.

Awal abad ke 20 keranjingan budaya Jepang di Eropa terutama di Perancis membuat senimannya mengadopsi karakter seni Jepang, Van Gogh sebagai seniman yang gelisah dengan sengaja mengcopy beberapa cetakan cukilan kayu Jepang menjadi lukisan post Impresionis.

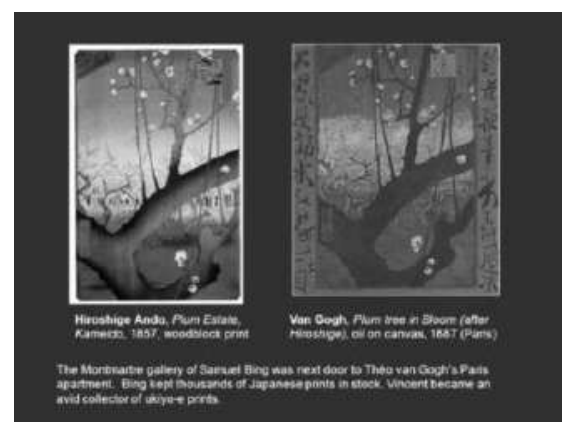

Gambar 1. Karya cetakan Hirosige Andro yang di lukis oleh Van Gogh

Karya makan di rerumputan Edward Manet mengadopsi karya illustrasi grafis Raimondi, apa yang dilakukan oleh Manet disebut sebagai Qouting, yaitu mengambil sebagian karya yang sudah ada sebagai inspirasi karyanya sebagai bentuk kreatifitas.

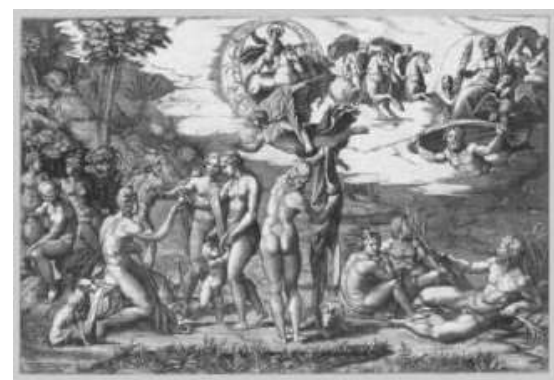

Gambar 2. Marcantonio Raimondi, The Judgement of Paris, 29,7 x 43,7 cm. Engraving, tahun 1515

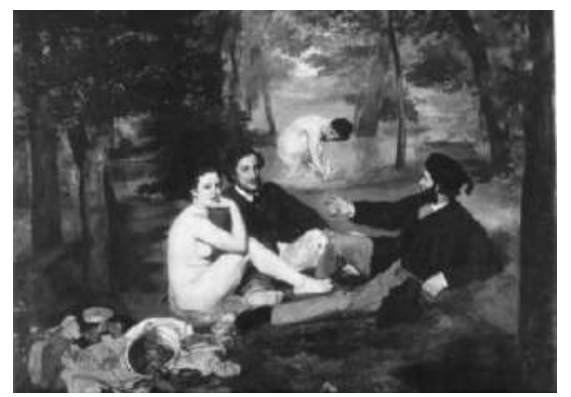

Gambar 3. Edward Manet, Le Dejeuner sur I'herbe 208,3 x 264,2 cm. Cat minyak pada kanvas, tahun 1862-3

Sikap nihilistik akibat perang yang berkecamuk membuat Marchel Duchamp lewat gerakan Dada nya, menampilkan Urinoar dengan ditandatangani entah nama siapa sebagai karyanya. Karya ini tentu tidak dapat diterima pada pameran kali itu, kehadiran bentuk ready made yang tidak asing sebahgai tempat buang air kecil, ditambah lagi dengan pertanyaan status seniman yang mencipta 
dirasa semena-mena menampilkan produk yang bukan buatannya.

Karya Roy Lichtenstein adalah bentuk apropriasi, mengusung aliran Pop Art, produk popular komik menjadi pilihannya dalam visual, dimana secara semena-mena dalam pengertian tidak merubah lalu membuatnya menjadi lebih besar sebagai karyanya.

Sebagai seniman Pablo Picasso menjadi musuh bagi kreatifitas teman-temannya, Picaso banyak mengadopsi lukisan terkenal merubahnya dengan menggunakan gaya kubistik, prilakunya ini menjadi bagian kreatifitas yang diakui dianggap jenius oleh para kritikus. Karya Velazguez Las Meninas menjadi inspirasi dan didikreasikan dalam bentuk kubistik dengan judul yang sama.

Dari apa yang diungkapkan diatas tentang kreatifitas yang lain tentu kita dapat mengambil kesimpulan, bahwa hal itu memang sudah lama terjadi seiring berjalannya perkembangan seni rupa. Tentu kreatifitas yang 'lain' akan juga berbenturan dengan norma yang memiliki nilai hukum, baik secara moral maupun perundangundangan tentang hak cipta. Dengan melihat kreatifitas yang lain juga kita dapat meruntut sejarah dalam-konteks sosial budaya seorang seniman, melihat problem sosial yang terjadi pada seniman.

\section{Peran Seniman Modern, Raden Saleh dan Basuki Abdullah}

Apabila menyebutkan tokoh penting dalam sejarah seni rupa modern Indonesia tentu akan sangat mudah menunjuk Raden Saleh dan Basoeki Abdullah, Raden Saleh hingga saat ini masih menempati posisi seniman Jawa pertama yang melukis dengan cara barat modern. Di dalam banyak pembahasan pelukis ini juga dikaitkan dengan sikap nasionalisme, walaupun terkesan dipaksakan sikap ini menurut bagi yang meyakini dikaitkan dengan lukisan Penangkapan Diponegoro serta sentimen persaksiannya atas berkecamuknya perang Jawa.

Raden Saleh dilahirkan tahun 1811 (Kraus, 2013) di Terboyo Semarang Jawa Tengah, seorang bangsawan keturunan dari Kyai Ngabehi Kertoboso Bustam (1681-1759), seorang residen Terboyo dan pendiri keluarga besar Bustaman yang menghasilkan para residen, patih dan anggota utama kelas priyayi bangsawan. (Bachtiar, Harsja W., Peter B.R. Carey, 2009:3)

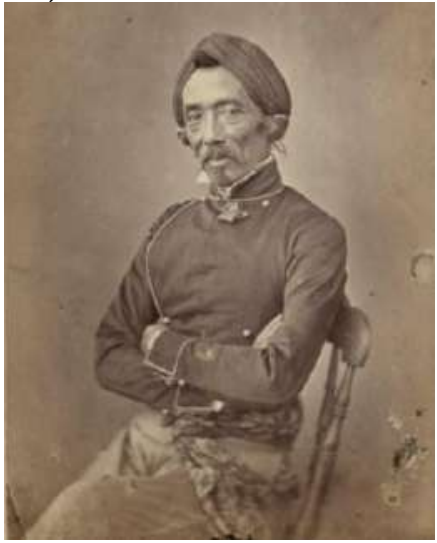

Gambar 4. Foto Raden Saleh sekitar tahun 1869

Raden Saleh menghabiskan masa kecilnya dikediaman Adipati Suoero Menggolo, Bupati Semarang di Terboyo, pamong yang berpikiran luas dan maju, seorang anggota perkumpulan pejabat tinggi Belanda eksklusif Javaansch Weldadig Genootschap (masyarakat filantropi), kegiatan paman dan kedekatan dengan pegawai Belanda tersebut yang kemudian dikaitkan dengan minat Raden Saleh pada seni lukis dan kebudayaan Eropa. ((Bachtiar, Harsja W., Peter B.R. Carey, 2009: 4-5)

Dorongan berkarya Raden Saleh semakin menemukan jalan dengan bertemu seorang pelukis berdarah Belgia Antonie Auguste Joseph Payen di Cianjur, pelukis seni pemerintah ini sedang bertugas melukis botani arahan professor C. G. C. Reinward. Raden Saleh mulai mengembangkan bakatnya dengan belajar dan tinggal bersama Payen ke Bogor. (Bachtiar, Harsja W., Peter B.R. Carey, 2009: 5) Keluarga kebangsaan Belgia Jean Baptiste de Linge membawa Raden Saleh ke Eropa dalam perjalanan 1829. Biaya hidup Raden Saleh didanai Javaansch Weldadig Genootschap, kemudian ditopang biaya kas koloni dan menjadi "anak negara" yang diawasi langsung oleh Kerajaan Belanda, melalui Direktorat Urusan Koloni Timur Jean Chretien Baud. (Bachtiar, Harsja W., Peter B.R. Carey, 2009:8) Berbagai program yang di tempuh dalam pendidikan Eropanya, membuat hidup Raden Saleh menjadi mandiri dan berpikiran terbuka, ditambah dengan kehidupan dengan para bangsawan Eropa membawa Raden Saleh 
masuk dalam lingkaran borjuis, ia sering diperkenalkan sebagai le prince javanais pada pertemuan Eropa, walaupun tidak begitu adanya, ia sering muncul dalam pakaian kebesaran yang sebagian Jawa dan sisanya dikarang sendiri. (Bachtiar, Harsja W., Peter B.R. Carey, 2009: 11) Hubungan Raden Saleh dengan kalangan borjuis dinegosiasi dengan penghadiahan lukisannya kepada Raja dan Kaisar Eropa. Bakat melukis Raden Saleh memunculkan kekagunan yang berlanjut dengan penganugrahan gelar bangsawan. Di Belanda Raden Saleh bertemu dengan beberapa Raja yang menganugrahkan gelar kebangsawanan, Gelar kebangsaan selanjutnya adalah Gelar Kehormatan dan Kesatria (Ritter) dengan Bintang dari Orde Fanz Joseph Kaisar Austria, dan ketiga adalah Kesatria Orde Tahta dari Kaisar Prusia, Wilhelm I pada tahun 1861. (Bachtiar, Harsja W., Peter B.R. Carey, 2009)

Raja Louis Philipe membuka jalan pertemanan Raden Saleh dengan para bangsawan Prancis. Raden Saleh menjalankan niatnya mempelajari karya-karya maestro pelukis besar dan intelektual di kota seniman tersebut. Kota itu adalah barometer keberhasilan dan tempat ujian baginya, selain tempat mendalami seni lukisnya juga menjadi ajang menunjukkan eksistensi sebagai seniman. Raden Saleh dapat menghasilkan karya-karya terbaik sehingga dia ikut serta di Salon pada 1847 untuk tampil di Luvre, namun seiring berjalannya waktu tentu besarnya seni di Paris tidak dapat memanfaatkan ketenarannya dalam waktu lama, dan tragisnya beberapa karyanya ikut terbakar dalam pemberontakan Prancis (Kraus, 2013: 57)

Meninggalkan Prancis menuju Belanda, pada tahun 1849 Raja William III menganugrahkan gelar resmi Raden Saleh sebagai "Pelukis Sang Raja", gelar sebagai penghormatan terhadap prestasi Raden Saleh dalam berkarya, dipandang juga sebagai usaha membantu memfasilitasi reintegrasi sang pelukis dengan tanah airnya.

Kepulangan kekampung halamannya tahun 1852, Raden Saleh menuju Jawa Tengah dan dekat dengan seorang janda kaya berkebangsaan Belanda, bersama istri dan kebangsaan Belandanya di Batavia, mereka membangun sebuah villa Neo Gothik berdasarkan petunjuk dan desain Raden Saleh sendiri. Villa Raden Saleh bersama istrinya yang pertama menjadi saksi atas produktifitas melukis serta aktivitas ilmiahnya, sebagian ruang bangunan tersebut dipakai untuk memajang koleksinya berupa sejata antik seperti keris dan tombak, manuskripmanuskrip kuno, dan tentu beberapa koleksi lukisan Eropa miliknya, dan sebagian besar koleksi penting tersebut telah dihibahkan kepada pemerintah kolonial kerajaan Belanda, serta menjadi benda ikatan pertemanan dengan bangsawan dan keluarga kerajaan Eropa.

Pengaruh kehidupan Eropa yang penuh dengan semangat eksplorasi dan pengetahun masa Victorian, memunculkan minat Raden Saleh dalam penggalian arkeologi yang menempatkannya bukan sekedar sebagai pelukis namun juga sebagai ilmuan, sejarah dan juga kolektor barang antik.

Semenjak remaja Raden Saleh telah dilibatkan dalam riset dibidang botani dan zoology oleh profesor kimia Casparus Georgius Carolus Reinwardt yang tiba di Batavia pada 1816. Masa dewasanya di Eropa kemungkinan Raden Saleh terlibat dalam kegiatan ilmiah dengan menjadi anggota pertama, dan satu-satunya donor dari Hindia Belanda di Koninklijk Iinstituut voor Taal-Land en Volkenkunde (Institute Linguistik dan Antropologi Kerajaan-KITLV) yang berpusat di Delft, Belanda. Badan ini mengeluarkan Jurnal yang berisikan artikel ilmiah dari bidang Filologi, sejarah, linguistik, arkeologi dan antropologi (Bachtiar et all, 1999:56).

Hubungannya dengan Istri Indo Belandanya Constancia Winkelman akhirnya pupus ditengah jalan, dan Raden Saleh yang telah berumur 57 tahun kemudian menikahi gadis muda Raden Ayu Danudirjo sepupu Sultan Jogja, Hamengku Buwana VI. Pernikahannya menjadi usaha penguatan statusnya sebagai bangsawan pribumi dan borjuis Eropa.

Raden Saleh mengunjungi Eropa dalam dua tahap, perjalanan pertamanya penuh dengan kehangatan dan kemegahan sambutan, namun berbeda halnya dengan perjalanan keduanya yang menurut Kraus, konon telah menghabiskan koleksi antik, serta meninggalkan hutang di tanah kelahirannya sendiri. Setelah sakit hati atas tuduhan 
subversifnya sebagai pemberontak di Jawa, Eropa yang diharapkannyapun sudah banyak berubah, kekecewaan itu semakin lengkap dengan usia lanjut yang sudah menyelimutinya ditambah keadaan istri yang mengalami sakit keras hingga kepulangannya ke Hindia Belanda.

Raden Saleh menghabiskan masa tuanya di Bogor, pada tahun 1880 mendapati istrinya yang sakitnya semakin parah ia membeli sebidang tanah untuk pemakaman, namun kenyataanya pada hari 23 April 1880, Raden Saleh yang paginya bugar dinyatakan wafat pada sore harinya. Sebelum kematian menjemputnya Raden Saleh sempat menyatakan kecurigaanya terhadap pembantu yang dilaporkan atas kecurigaan pencurian lukisan telah meracuninya, namun hasil otopsi menunjukkan bahwa Raden Saleh mengalami serangan thrombosis, penggumpalan darah di pembuluh jantungnya yang menyebabkan terhentinya sirkulasi darah (Kraus, 2013).

Basoeki Abdullah lahir tanggal 27 Januari 1915 di Solo, kelahirannya diwarnai dengan ritus tradisional Jawa sebagaimana keluarga bangsawan Kraton. Ayahnya adalah seorang pelukis modern R. Abdullah Suryo Subroto dan ibunya R. Ngt. Ngadisah adalah seorang putri pembatik. Disamping itu dari garis ayah R. Basoeki Abdulah adalah cucu dari Dr. Wahidin Sudirohusodo seorang yang aktif dalam pergerakan modern Jawa.

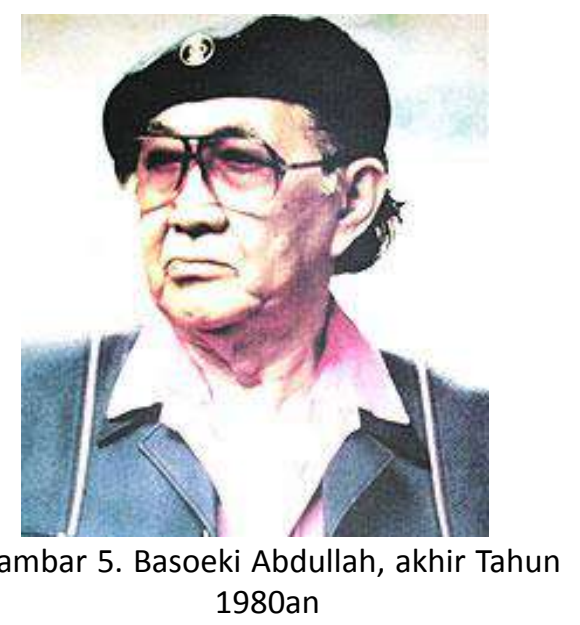

Basoeki Abdullah kecil hidup dalam suasana Kraton Kasunanan Surakarta, paman sekaligus bapak angkatnya Dr. Sulaiman Mangunhusodo adalah dokter pribadi Sri Sunan Pakubuwono X, hubungan pamannya dengan kraton yang berpengaruh pada kepribadian aristokratis Basoeki Abdullah, dia juga memiliki guru spiritual Sasrokartono yang mewarnai sikap keseniannya dalam balutan mistis.

Berkreasi secara modern menggunakan goresan pensil, cat air atau cat minyak tentu tidak bisa dilepaskan atas pengaruh ayah dan kebersamaan saudara-saudaranya yang juga melukis. Seiring berjalannya waktu kemampuan melukis Basoeki Abdullah semakin terasah, sehingga banyak pesanan yang mampir kepadanya, ketenarannya akhirnya memberikan kesempatan kepadanya untuk memamerkan karya di Jaarbeurs, pekan raya Bandung, melalui rekomendasi Prof. Wolff Schoemacher guru dari Technische Hoogenschool Bandung.

Atas Jasa Romo Pastor Kohc, SJ. Basoeki Abdullah mendapatkan beasiswa untuk mengikuti pelajaran di Koninklijke Akademic van Beeldende Kunsten, Den Haag Belanda. Kemudian dilanjutkan mengikuti pelajaran semacam studi banding di Akademi seni rupa Prancis dan Roma. Kesempatan ke Eropa membuat Basoeki Abdullah dapat melihat langsung lukisan-lukisan bersejarah modern pada museum, dan tentu sangat memungkinkan bagi munculnya keterpikatan pada teknik dan tema yang ditemuinya.

Perjalanan berkesenian Basoeki Abdullah berada pada masa ambang revolusi di tanah airnya, kedekatannya dengan Belanda sebagai sponsor pendidikan dan kesempatan tamasya estetik dimuseum-museum Eropa, pada saat yang sama seniman seangkatannya sedang dalam masa revolusi fisik, dan menguras pikiran untuk melepas dari kungkungan penjajahan, situasi ini memberi pengaruh perlakuan beberapa seniman pergerakan tanah airnya. Besarnya pengaruh politik yang terjadi menempatkannya sebagai pelukis mooi indie sebutan yang sebenarnya bertujuan merendahkan.

Keterlibatan politik Basoeki Abdullah terjadi ketika ia menjadi corong Jepang bergabung dengan Poetra bertugas mengajar seni lukis, serta aktif dalam Pusat Kebudayaan milik Jepang, organisasi Keimin Bunka Sidhoso bersama Affandi, S. Sudjojono, namun keterlibatannya pada politik praktis hanya merupakan formalitas terutama untuk 
memanfaatkan fasilitas Jepang untuk berkarya. Namun kedekatannya dengan orong-orang pergerakan politik, terutama pada masa pendudukan Jepang membuat pernikahan dengan wanita belandanya hancur, ia disebut sebagai mata-mata dan berkhianat terhadap patronnya, menjadi alasan bagi bercerainya Basoeki Abdullah dengan Maya.

Basoeki Abdullah menjalani kehidupan berkeseniannya melewati kemelut sejarah, sempat di cap sebagai seniman mooi indie dalam masa revolusi yang sibuk mencari identitas kebangsaan. Cacian datang dari S.Sudjojono yang memiliki karisma sebagai seniman yang sibuk dalam pencarian identitas keindonesiaan, ketidakperdulian Basoeki Abdullah didukung oleh statusnya memiliki teman dekat politikus nomor wahid saat itu, hal yang paling menguntungkan baginya adalah peran Soekarno sebagai pelipur lara, pencinta seni yang sangat antusias terhadap karya-karyanya. Hubungan Basoeki Abdullah dan Soekarno terjalin atas banyak kesamaan ketertarikan diantara mereka terutama perempuan cantik.

Kehidupannya dalam berkeluarga Basoeki Abdullah berturut-turut menikah dengan dua wanita Eropa yaitu Josephine dan Maya Michel, pernikahannya yang gagal digenapi secara berturut-turut dua wanita berasal dari Thailand, Somwing Noi, dan akhirnya menikahi Nataya Narerat yang menemani hingga akhir hayat dilampauinya. Pernikahan awalnya bersama wanita Eropa merupakan bagian dari masa studinya, produktifitasnya menjajaki beberapa pameran yang diselenggarakan di beberapa negara dan juga Hindia Belanda, dapat dikata bahwa masa ini merupakan penjajakan kehidupan keseniannya. Sedangkan pernikahan dengan wanita Thailand menjadi masa penjajakannya memasuki ruang-ruang Istana dan bertemu dengan orang orang penting dunia.

Karya-karya Basoeki Abdullah menjadi sangat disukai oleh istana-istana, perannya dapat memasuki kerajaan Kamboja, Philipina, Thailand dan Brunei. Prestasinya tersebut sebagai penanda yang disematkan padanya Duta Seni Lukis Indonesia sebagaimana tulisan Agus Dermawan T. (Dermawan, 1985) Peran hidup berkesenian Basoeki Abdullah yang dirintisnya mendapat tempat yang nyaman ketika masa Orde Baru. Keenggananya dalam memasuki dunia politik serta kecanggihannya dalam melukis mengundang banyak pejabat, artis dan orang-orang penting untuk dilukis olehnya.

Dalam berkarya Basoeki Abdullah memegang teguh prinsip Naturalistik Romantik sebagai alirannya, walaupun pada penghujung kreatifitasnya membuat beberapa karya menuju ke abstrak sebagai coba-coba, dimana kepuasan capaian terhadap aliran yang ditekuni sejak awal belum ia dapatkan. Dia juga mengungkapkan tentang orisinalitas karya modern seratus persen adalah sesuatu yang kurang masuk akal. (Dermawan, 1985: 93) Basoeki Abdullah mengakui beberapa seniman memang memberi pengaruh pada kesenilukisannya, namun ia juga bertanggung jawa dengan memberikan jiwanya pada karya yang dicipta.

\section{Problem kultural, Identifikasi Karya}

Sejak diciptakan kehidupan manusia berjalan dengan dinamis, hal ini berhubungan dengan usaha manusia untuk berperan dalam kehidupannya sebagai mahluk sosial. Banyak teori yang dikemukakan untuk memahami fenomena sosial masyarakat berkaitan dengan peran individu, salah satunya adalah Bourdieu dengan melihat dualisme peran "agensi" (individu atau tindakan individu) dan "struktur". untuk mendamaikan keduanya dalam membaca dan menganalisa struktur masyarakat, gejala sosial, perubahan sosial dan lainnya, ia menautkan peran agen dan struktur dengan mengajukan konsep babitus, capital, dan field sebagai kata kunci. (Harker, Richard, 2009)

Kedudukan Raden Saleh dan Basoeki Abdullah dalam percaturan seni rupa memakai nafas modern dalam kreatifitasnya, dikenal sebagai seorang Jawa yang melukis secara modern. Dalam kancah seni rupa modern dua tokoh ini menjadi landasan langkah bagi kreatifitas pribumi Indonesia yang mendunia, menjadi pelukis memasuki aliran-aliran seni rupa modern yang mereka pilih sebagai jalan hidup kesenian mereka. Mereka mengikuti arus aliran perkembanan seni rupa modern, semangat kreatifitas, orisinalitas dan kebaruan dalam semangat modern mereka arungi dengan modal sosial dan teknis tentu materi dalam 
menempati kedudukan dalam arena seni rupa. Kecenderungan kreatifitas yang mereka pilih romantis dan naturalis romantis, mahzab bagi kesadaran intelektualnya dalam konteks mengambil peran dalam percaturan seni rupa dunia.

Raden Saleh dan Basoeki Abdullah masuk dalam ambang antara kepribadian tradisional sebagai latar belakang kehidupannya dan menghadapi struktur modern dalam kreatifitas, kegamangan melewati struktur dibayar dengan keberhasilan seni rupa mereka, mereka berhasil membuka pintu dunia modern untuk mengkonfirmasi kehidupan, kreatifitas dan artefak seni modern yang menjadi inspirasi mereka. Dunia modern memfasilitasi kehausan mereka terhadap kreatifitas dalam melukis, Raden Saleh dan Bosoeki Abdullah mencoba melukis sebagaimana orang Eropa berkarya.

Momentum romantikisme Raden Saleh adalah bertemu Horace Vernet, mendorong untuk membuat lukisan versi lain dari seniman tersebut. Usahanya dengan mengambil beberapa gestur kuda Vernet, namun tentu Raden Saleh memberikan banyak sentuhan yang membuat karyanya menjadi tetap berbeda melalui cerita yang berbeda pula. Karya tersebut konon mendapat pujian langsung dari Horace Vernet yang menunjukkan bahwa Raden Saleh melukiskannya dengan kesadaran.

Raden Saleh hidup pada masa Romantisme berlangsung mewarnai seni rupa di Eropa, objek-objek yang muncul adalah berkenaan dengan pandangan Eropa tentang orientalisme, sehingga figur-figur badui Arab, pertarungan antar binatang dan cahaya jingga, dan cerita romantik muncul di pada karya lukisannya sedangkan lukisan tentang perburuan hewan sebenarnya sudah ada sejak jaman Renaisans akhir.

Raden Saleh membandingkan sentimen lukisannya dengan ciptaan orang Eropa yang tidak memiliki kedekatan dengan situasinya, lukisan yang diciptakannya lebih memiliki kedalaman sebagaimana pandangan Jawanya lebih kepada persoalan mental dan bukan pada visual semata (Kraus, 2018: 109).

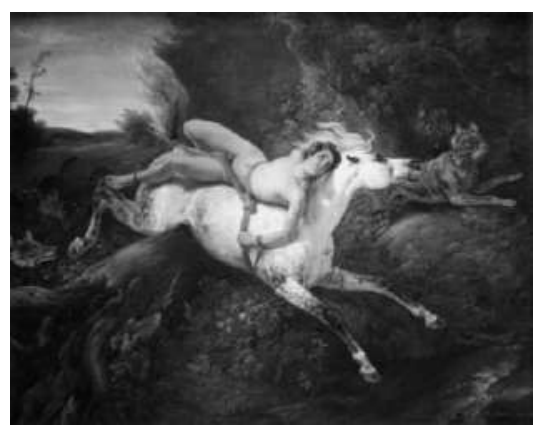

Gambar 6. Horace Vernet, Mazepa, 97x $136 \mathrm{~cm}$. Cat minyak pada kanvas tahun 1826

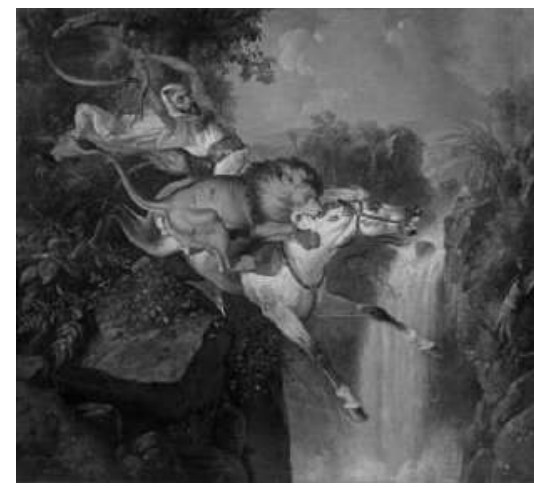

Gambar 7. Raden Saleh, "Penunggang Kuda Arab Diterkam Singa", 154 x 165,5 Cm. Cat Minyak Pada Kanvas, tahun1842

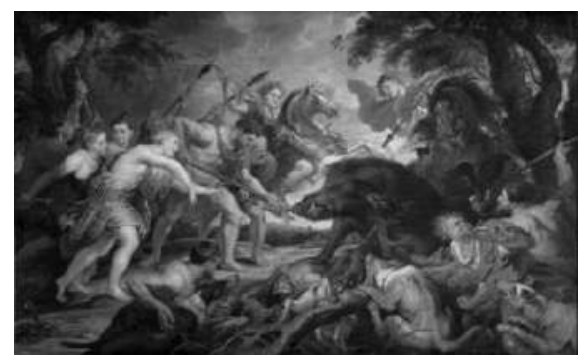

Gambar 8. Peter Paul Rubens, Meleager and Atlanta and the Hunt of the Calydonian Boar, tahun 1620

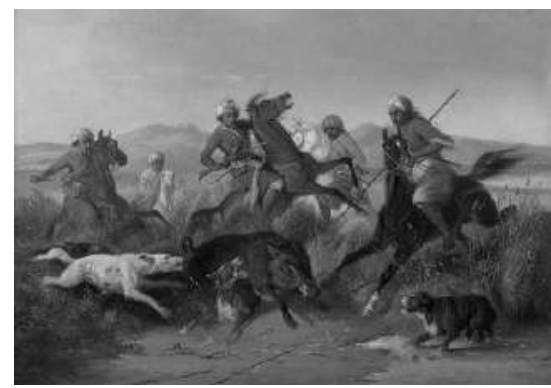

Gambar 9. Raden Saleh, A Boar Hunt in Java, $37.5 \times 52.6 \mathrm{~cm}$ 


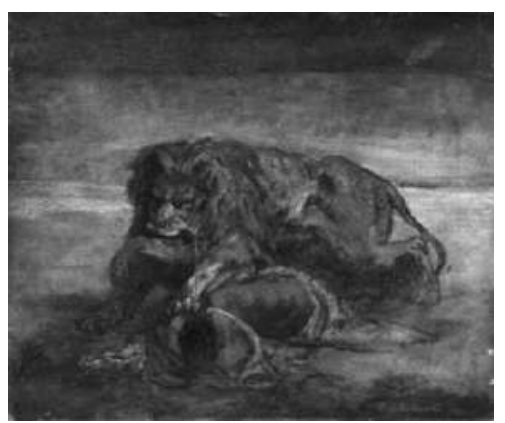

Gambar 10. Eugine Delacroix, Lion Devouring an Arab, 54,1 x 65,4 cm.

Cat Minyak pada Kanvas, tahun 1850

Penangkapan Diponegoro adalah karya fenomenal dari Raden Saleh, dibuat ketika ia berada di Batavia sedang beristrikan seorang nyonya Belanda. Karya tersebut identik dengan lukisan Pieneman seorang seniman berdarah Belgia atas pesanan De Kock. Raden Saleh tentu tahu dan mungkin pernah melihat lukisan Pieneman yang sudah lebih dahulu ada. Salah satu sentimen keinginan Raden Saleh melukiskan penangkapan Diponegoro adalah berita kematian sang pangeran dua tahun sebelum karya tersebut selesai, lahirnya lukisan Penangkapan Diponegoro dikaitkan dengan simpati Raden Saleh sebagai sesama orang Jawa, dan memperlihatkan sudut pandang berbeda dari lukisan Pieneman.

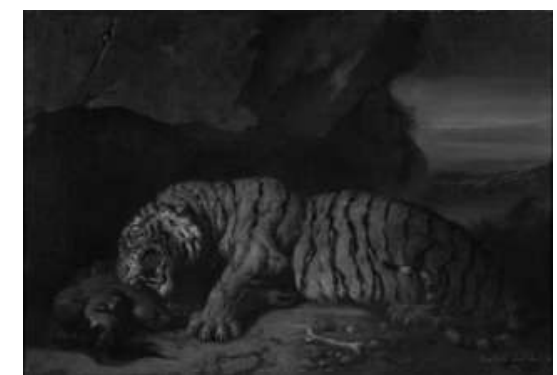

Gambar 11. Raden Saleh, Koningstijger met Prooi, $61 \times 92,5 \mathrm{~cm}$.

Cat minyak di Kanvas, tahun 1866

Dapat dikatakan lukisan Penangkapan Diponegoro adalah versi lain dari lukisan Pieneman. Kalau diperhatikan terhadap kedua lukisan tersebut dapat teridentifikasi beberapa kesamaan namun memang sengaja dibuat secara berbeda. Perbedaan terbesar ada pada sudut pandangnya, namun setting situasi penangkapan dibuat hampir sama, setelah perundingan drama di tangga bangunan,
Diponegoro sedang bersiap menaiki kereta kuda yang menunggu.

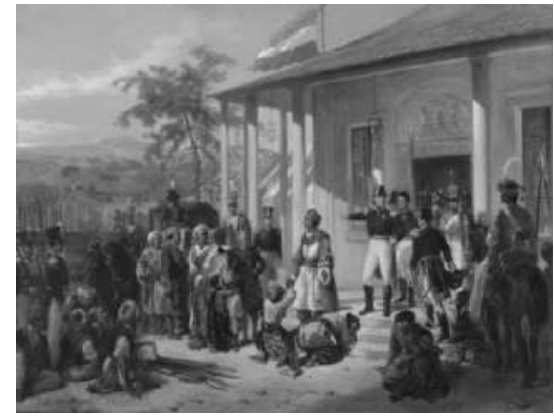

Gambar 12. Nicolass Pieneman

"The Submission of Diepo Negoro to Lt. Gen. H.M. de Kock, 28 March 1830". Cat Minyak di kanvas Rijksmuseum Amsterdam (Sumber: Kraus)

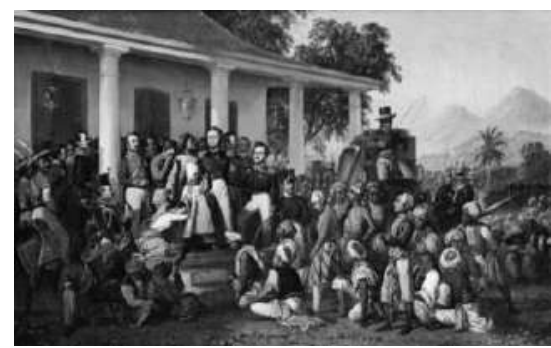

Gambar 13. Raden Saleh, "Penangkapan Diponegoro", 112 x $178 \mathrm{~cm}$

Cat Minyak di kanvas, 1857, Koleksi Istana Kepresidenan Republik Indonesia (Sumber: Mikke Susanto)

Lukisan ini adalah satu-satunya karya yang memiliki kompleksitas yang tinggi, sehingga menguji kemampuan akademis Raden Saleh. Walaupun menjadi lukisan yang sangat luar biasa namun dari lukisan tersebut terlihat kelemahan Raden Saleh dalam penguasaan proporsi dan perspektif, walaupun para peneliti lebih melihat sebagai sikap perlawanan dari Raden Saleh yang dilakukan melalui karyanya.

Lukisan Penangkapan Diponegoro karya Raden Saleh diciptakan untuk dihadiahkan kepada kerajaan Belanda, selain sebagai usaha untuk mempertahankan eksistensinya di kalangan bangsawan Eropa, karyanya dapat disejajarkan dengan koleksi lukisan-lukisan seniman Eropa. Karya Penangkapan Diponegoro juga sebagai bentuk penghormatan kepada Kerajaan Belanda, ucapan terima kasih Raden Saleh yang telah merasa difasilitasi kehidupan keseniannya di Eropa. 
Dalam perjalanannya karya penangkapan Diponegoro tidak mendapatkan tempat yang layak di Belanda, tentu hal ini sangat mungkin terjadi akibat tidak bisa dilepaskannya persepsi Belanda terhadap sosok Diponegoro sebagai pemberontak. Sempat menghuni rumah sakit di Belanda, karya ini sekarang menjadi koleksi Istana kepresiden Republik Indonesia dan menempati sebagai karya penting dalam sejarah seni rupa Indonesia.

Lukisan tentang banjir di Jawa Raden Saleh secara mudah sering dikaitkan dengan lukisan Ralf of Medusa karya Gericault, sama dengan lukisan Penangkapan Diponegoro lukisan ini memiliki komposisi saling berlawanan. Karya ini memiliki tema yang sama tentang sebuah tragedi dengan semangat yang sama pula yaitu harapan. Ketika lukisan Watersnood op Midden Java selesai, karya ini di pajang di balaiurung rumahnya ia membuka pintu dengan memungut biaya bagi orang yang ingin melihatnya, hal yang sama dilakukan oleh Gericault dengan rakit Medusa. Raden Saleh menghasilkan $f 1.000$ untuk disalurkan kepada yayasan amal Djati-gesticht, menunjukkan bahwa ia bukan sekedar seniman tapi juga seorang darmawan (Kraus, 2018: 163)

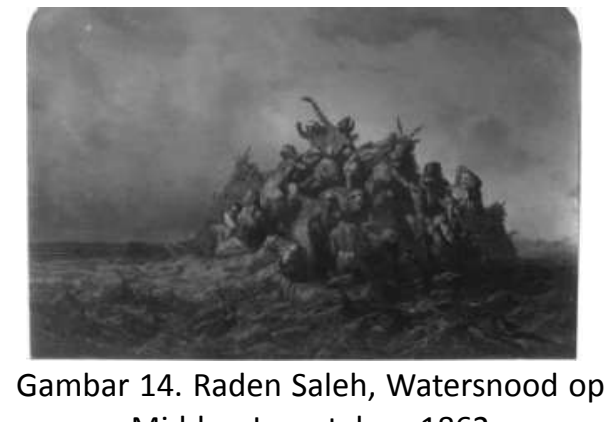
Midden Java, tahun 1862

Sebagai pelukis modern karya Basoeki Abdullah relatif dapat diterima dalam segala golongan, karyanya secara alami masih mengacu pada kenyataan dan mudah dinikmati oleh setiap kalangan, menyebut dirinya sebagai seniman Naturalis Romantik yang merupakan produk Eropa. Pandangan Basoeki Abdullah dalam seni rupa membebaskan dirinya untuk melukis berdasarkan keindahan yang dianutnya, tidak mau terjebak dalam dunia politik dan asik memunculkan objek yang dibuat lebih jelita dari model lewat goresan kuasnya.

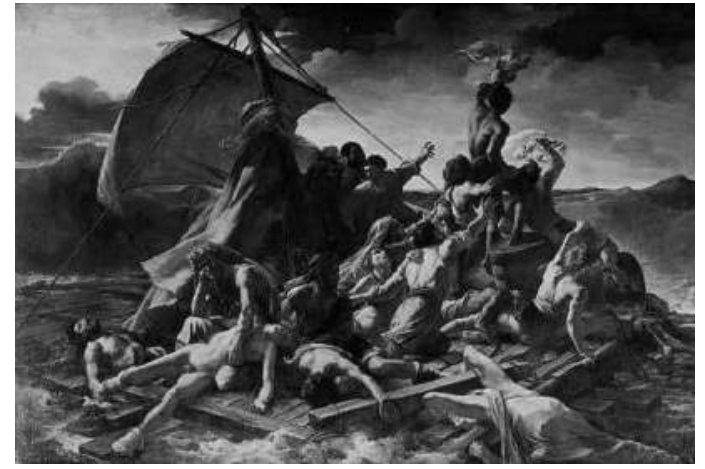

\section{Gambar 15. Theodore Gericault, Le Rodeau de la Medusa, $491 \times 716 \mathrm{~cm}$, tahun 1818}

$\mathrm{K}$ e $\mathrm{m}$ a $\mathrm{mpu}$ a $\mathrm{n}$ e $\mathrm{luk} \mathrm{is}$ Abdullah Suriosubroto yang naturalistik menurun pada beberapa anaknya, dan tentu salah satunya adalah pada Basoeki Abdullah. Berbeda dengan ayahnya yang lebih mendalami lukisan pemandangan dan souvenier, Basoeki Abdulah memiliki ketertarikan pada objek-objek yang lebih kompleks, yaitu potret dan figur, hal ini dimungkinkan karena ia hidup dalam masa yang lebih kompleks dalam kemudahan referensi.

Da la $\mathrm{m}$ masa perg era $\mathrm{k}$ a $\mathrm{n}$ kemerdekaan justr u Basoeki Abdullah memiliki kesempatan untuk mendalami ilmu melukis melalui Ko n i $\mathrm{n} \mathrm{j} 1$ i k e A k a d e m i e B e lde nde Kunsten. Basoeki Abdullah mengakui secara tema dan teknis dalam goresan melukisnya terpengaruh dari Pieter Adolfs dan beberapa seniman Eropa yang datang ke Indonesia.

Karya identik Basuki Abdullah terhadap seniman Eropa tidak lepas dari mulai tersedianya dokumen dan buku, ditambah dengan kesempatanya dapat ting gal untuk studi di Eropa yang memungkinkan baginya masuk ke museum-museum. Lukisan Ketika Tuhan Murka memiliki kaitan dengan lukisan John Martin terutama Francis Danby, kedatangannya di Eropa dan tentu dengan adanya salinan dokumentasi karya lukisan menginspirasi Basoeki Abdulllah untuk merangkum dua lukisan tersebut. 


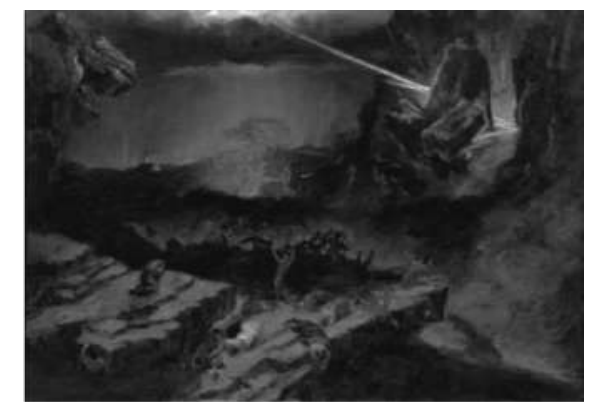

Gambar 16. Francis Danby, The Opening of the Sixth Seal, $50.1 \times 70.1 \mathrm{~cm}$ Cat minyak pada Kanvas, tahun 1828

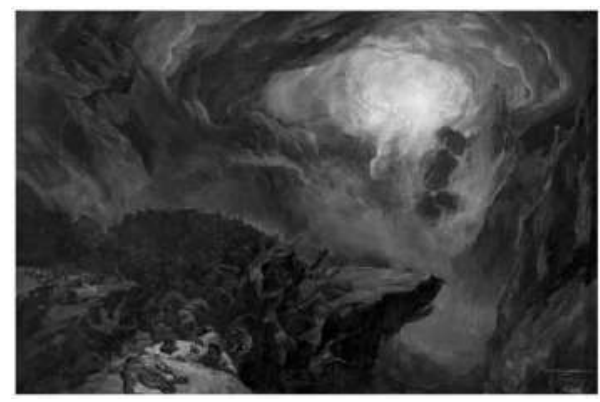

Gambar 17. Basuki Abdullah, Ketika Tuhan Murka,

200 x 300 cm. Oil on Canvas, 1950

Keleluasan Basoeki Abdullah dalam mengakses karya seni ketika tinggal di Eropa, dan menemui cetakan karya lukisan dokumentatif memberi peluang baginya untuk dapat berpapasan dengan karya yang kelak menjadi inspirasinya, salah satu yang terlihat adalah sosok Banteng pada lukisannya yang identik dengan yang ada pada lukisan Hutan Terbakar kepunyaan Raden Saleh. Gestur banteng yang mendongak kepalanya ini kemungkinan dibuat dengan mengacu pada reproduksi litografi milik Raden Saleh.

Sebuah karya dramatis tentang meletusnya gunung berapi milik Edwin Church dikembangkan menjadi dua lukisan milik Basoeki Abdullah tentang letusan gunung Krakatau.

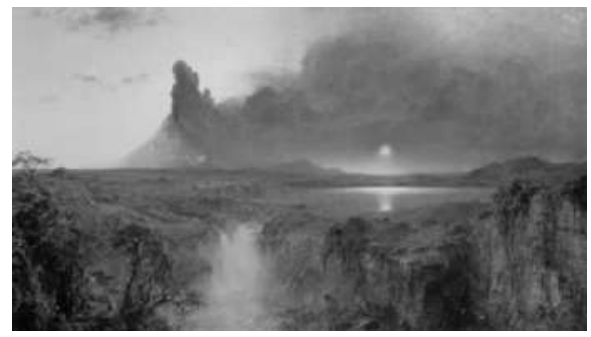

Gambar 18. Edwin Church, Cotopaxi, $121,9 \times 215,9 \mathrm{~cm}$, cat minyak di kanvas, 1862

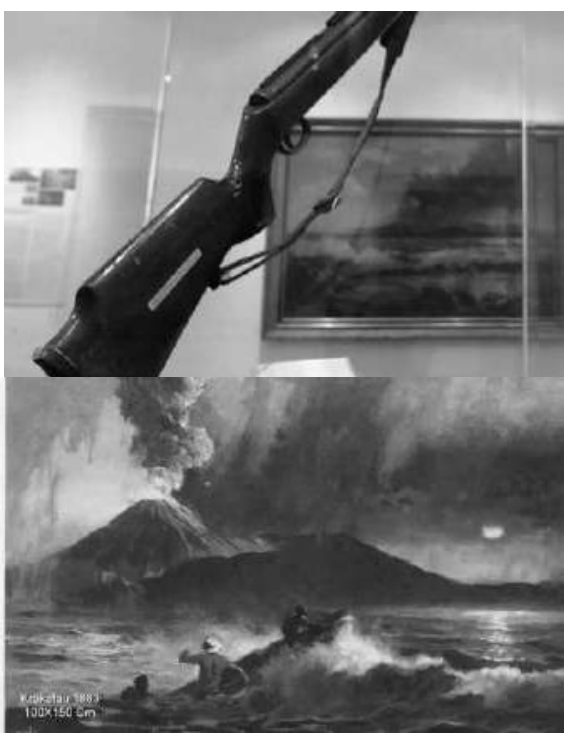

Gambar 19. Dua buah karya Basoeki Abdullah dengan tema Krakatau yang di buat tahun 1980an

Lukisan Chuch memberikan nuansa yang sangat menggoda bagi pelukis naturalis, terik matahari diselimuti oleh muntahan debu vulkanik memberikan drama diantara kecerahan langit biru dan warna panas sinar matahari. Kesederhanaan objek Church diganti dengan kontek krakatau yang merupakan pulau gunung merapi dan deburan ombak yang menghempas para nelayan.

Dan karya yang paling teridentifikasi secara terstruktur lukisan Basoeki Abdullah adalah lukisan berjudul pertarungan dengan harimau yang identik dengan lukisan Paul Rubens Lion Hunt. Karya lukisan Basoeki Abdullah secara jelas mengambil objek utama dari lukisan Rubens, walaupun berusaha untuk merubah beberapa unsur didalamnya namun stuktur utama dalam karya tersebut masih sangat kuat teridentifikasi.

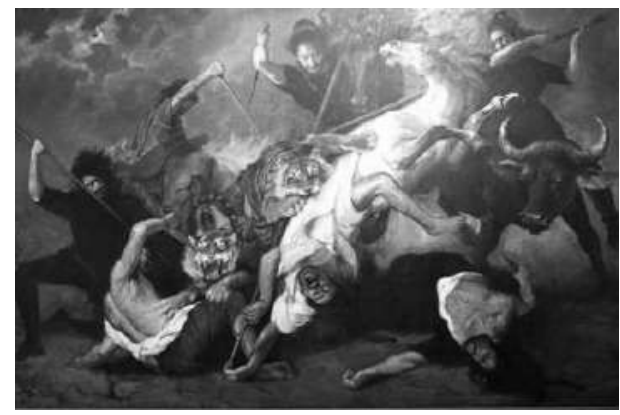

Gambar 20. Basoeki Abdullah, Pertarungan dengan Harimau, $320 \times 210 \mathrm{Cm}$, tahun 1988 


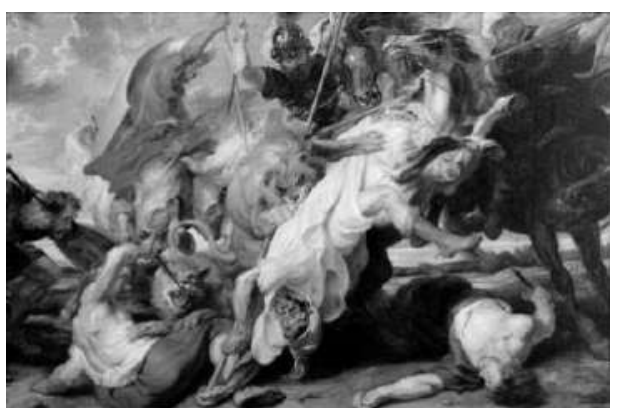

Gambar 21. Peter Paul Rubens, Lion Hunt, Oil on Canvas, tahun 1621

Dalam lukisan Basoeki Abdullah background dibuat dengan lebih gelap untuk memunculkan objek utamanya, dramatisasi kebesaran kekaisaran Romawi melawan singa milik Rubens di refleksikan menjadi para jagoan pribumi yang bertarung dengan harimau.

Dalam pengakuannya Basoeki Abdullah mendapatkan paras Diponegoro lewat semedi yang dilakukannya, sehingga dapat menghadirkan sang pangeran bersama Nyai Loro Kidul langsung di hadapannya, sang pangeran menurutnya sering menunduk sebagai sebuah penghormatan terhadap Nyi Roro Kidul. Dari situasi itu Basoeki Abdullah dapat menangkap wajah Diponegoro dan meyakinkan bahwa paras yang paling mendekati karakter wajah Diponegoro ada pada lukisannya. Sebuah kenyataan pula bahwa potret Diponegoro yang sering hadir dalam lukisan-lukisan di Indonesia, sebagian besar kemudian mengacu pada paras yang ada pada lukisan Basoeki Abdullah.

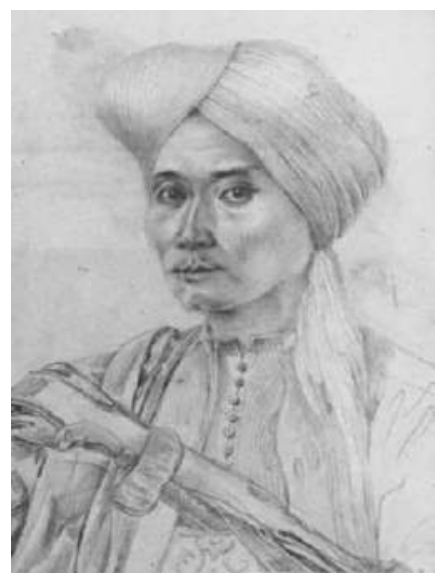

Gambar 22. Basuki Abdullah "Potret Diponegoro" 87 x $60 \mathrm{~cm}$ Cat minyak pada kanvas, 1976

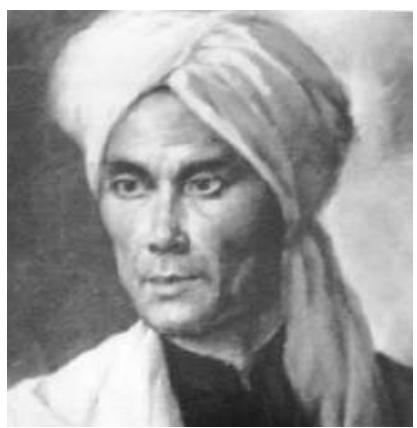

Gambar 23. A.J. Bik "Potret Diponegoro"

150x120 cm Graphit pada kertas 1830

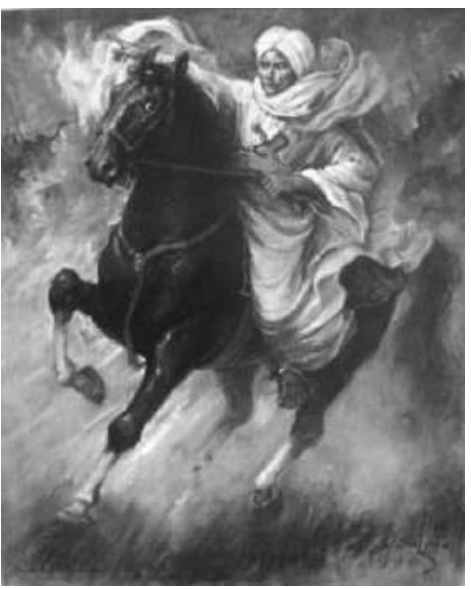

Gambar 24.Basuki Abdullah "Diponegoro Memimpin Pertempuran" 150x120 cm. Cat minyak pada kanvas.

Sesungguhnya tidak dapat dipungkiri bahwa paras wajah Diponegoro yang paling mendekati aslinya adalah pada drawing yang dibuat pada tahun 1830, karya Adrianus Johannes Bik yang langsung menggambar wajah Diponegoro di kapal laut saat mengikuti sang pangeran ke tempat pengasingannya, sangat mungkin Basoeki Abdullah yang lahir setelahnya telah melihat atau memiliki cetakan dari drawing tersebut.

Karakteristik paras Pangeran Diponegoro milik Bik masih dapat terlacak dari sudut pandang yang identik dengan yang dimiliki Basoeki Abdullah. Ketika di buat oleh Bik, di hadapannya Diponegoro masih dalam keadaan sakit malaria sehingga tulang pelipisnya menonjol, tentu ketika kondisi normal tulang pelipis dan mata cekung yang dimiliki Diponegoro tidak akan terlalu nampak, dan jejak-jejak ini masih terbaca pada lukisan Basoeki Abdullah. 


\section{Kesimpulan}

Pada penelitian ini mengangkat seniman modern Jawa Raden Saleh dan Basoeki Abdullah, pilihannya melukis secara modern menghadapkan problem kultural dalam penciptaanya. Terdapat keyakinan bahwa melukis orisinalitas seorang seniman modern menjadi tuntutan utama, membuat karya yang baru sebagai bentuk kreatifitas yang berkepribadian, mereka juga melakukan kreatifitas dengan mengidentifikasi terhadap karya yang sudah ada dianggap memiliki nilai yang negatif.

Fenomena yang dilakukan oleh Raden Saleh dan Basoeki Abdullah, betapa seniman besar sekalipun pernah melakukan cara kreatifitas yang teridentifikasi dengan seniman lain, hal ini kita dapat memandangnya sebagai bentuk kreatifitas "lain" dari seni rupa modern. Sebagai agen yang menghadapi struktur kreatifitas mereka ditelaah dalam habitus, modal dan arena yang mereka jalani.

Kepribadian Jawa yang berbenturan dengan semangat modern mengiringi usaha Raden Saleh dan Basoeki Abdullah menempuh jalan keseniannya. Mereka menjadi agen seni rupa modern dan berhadapan dengan struktur dalam perjalanan kehidupannya. Membentuk habitus yang menuntut eksis dalam dunianya, tentu usaha ini ditunjang dengan modal sosial dan ekonomis, hidup dalam lingkungan sosial yang mapan sehingga memungkinkan seorang seniman untuk dapat mengkomfirmasi dan berhadapan langsung dengan karya-karya masterpiece, menguasai informasi sehingga memunculkan kekaguman, hingga lebih jauh lagi menghadirkan gagasan untuk memproduksi ulang sebuah kekaguman. Secara tidak langsung Raden Saleh dan Basoeki
Abdullah menjadi agen dalam penyebaran ide maupun informasi modernitas tersebut walaupun dengan karya melewati kreatifitas yang "lain".

\section{Daftar Pustaka}

Agus, D. T. (1985). R. Basoeki Abdullah RA.:

Duta Seni Lukis Indonesia. Jakarta:

Gramedia.

Annas, B. (2000). Refleksi Seni Rupa Indonesia, Dulu, Kini, dan Esok. Jakarta: Balai Pustaka.

Bachtiar, Harsja W., Peter B.R. Carey, O. (2009). Raden Saleh, Anak Belanda, Moi Indie \& Nasionalisme. Jakarta: Komunitas Bambu.

Effendy, R. (2007). Dalam Apropriasi: Spektrum Praktek. Apropriasi Dalam Seni Rupa Kontemporer di Indonesia. Semarang.

Harker, Richard, dkk (ed. . (2009). (Habitus $x$ Modal) + Ranah =Praktik; Pengantar Paling Komprehensif Kepada Pemikiran Pierre Bourdieu". Yogyakarta: Jalasutra.

Hasan, A. (2005). Kamus Besar Bahasa Indonesia. Jakarta: Balai Pustaka.

Kraus, W. (2013). Raden Saleh, Awal Seni Lukis Modern Indonesia. Jakarta: Goethe Institut Indonesia.

Kraus, W. (2018). Raden Saleh, Kehidupan dan Karyanya. Jakarta: KPG.

Ratna, N. K. (2010). Metode Penelitian, Kajian Budaya dan Ilmu sosial Humaniora Pada Umumnya. Yogyakarta: Pustaka Pelajar.

Sumartono. (2017). Metode Penelitian Kualitatif Seni Rupa \& Desain. Jakarta: Pusat Studi Reka Rancang Visual dan Lingkungan FSRD Universitas Trisakti. 